\title{
SUSU KECAMBAH KEDELAI BASAH KAYA PROTEIN DISUKAI SEBAGAI MINUMAN ALTERNATIF UNTUK OBESITAS
}

\author{
The wet of milk sprouts-soybeans rich in protein like as an alternative drinks for \\ obesity
}

Hery Winarsi ${ }^{1}$

${ }^{1}$ Program studi Ilmu Gizi, Fakultas Ilmu-ilmu Kesehatan, Universitas Jenderal Soedirman

Alamat korespondensi: winarsi12@gmail.com; hery.winarsi@unsoed.ac.id

\begin{abstract}
This study aims to compare the level of organoleptic and protein content of milk sprouts-soybeans made by wet and dry method. Through the wet method, the milk sprouts-soybeans was made from sproutssoybean that have been cleansed of dirt and cotyledon, added milk, sucrose, and a small amount of salt, and water, blended finely, then filtered, boiled, and allowed to cool. But, the milk sprouts-soybeans made in a dry method begins with making soybean sprouts, then prepared on the flour of soybean-sprouts, sucrose, skim milk, and salt. The dry milk needs to be brewed with hot water, stirred until homogeneous. A total of 52 panelists consisting of students, employees, and ladies of PKK Purwosari and Pamijen, conducted organoleptic tests including color, flavor, aroma, and viscosity, with scoring scales 1-5; where $1=$ dislike extremely, $2=$ dislike moderately, 3 = slightly dislike, 4 = like moderately, and $5=$ like extremely. The protein content was determined by microKjeldhal. The result, the wet method of milk sprouts-soybeans was preferred, with a protein content of $13.771 \%$. One serving of the wet of milk sprouts-soybeans $(250 \mathrm{ml})$ can supply protein intake of 34.43 $g$ equal to 60.40-61.48\% of the need for protein for some age groups. Thus, the wet of milk sprouts-soybeans potentially as weight loss in obesity.
\end{abstract}

Keywords: the wet of milk sprouts-soybeans, the dry of milk sprouts-soybeans, protein, obesity.

\begin{abstract}
ABSTRAK
Penelitian ini bertujuan untuk membandingkan tingkat kesukaan dan kandungan protein susu kecambah kedelai (sumbae) yang dibuat dengan cara basah dan cara kering. Melalui cara basah, sumbae dibuat dari kecambah kedelai yang telah dibersihkan dari kotoran dan cotiledonnya, ditambahkan susu, sukrosa, dan sedikit garam, serta air, diblender hingga halus, kemudian disaring, dididihkan, dan dibiarkan dingin. Sumbae yang dibuat dengan cara kering, diawali dengan membuat tepung kecambah kedelai, kemudian disusun atas tepung kecambah kedelai, sukrosa, susu skim, dan garam. Sumbae kering perlu diseduh dengan air panas, diaduk-aduk hingga homogen. Sebanyak 52 panelis terdiri dari mahasiswa, karyawan, dan ibu-ibu PKK Desa Purwosari dan Pamijen, melakukan uji organoleptic meliputi warna, rasa, aroma, dan kekentalan, dengan metode scoring berskala 1-5; 1 sangat tidak suka, 2, tidak suka, 3, agak tidak suka, 4, suka, 5, sangat suka. Kadar protein ditentukan dengan mikroKjeldhal. Hasilnya, sumbae cara basah lebih disukai, dengan kandungan protein sebesar $13,771 \%$. Satu takaran saji sumbae basah $(250 \mathrm{ml})$ dapat memenuhi asupan protein sebesar 34,43 $\mathrm{g}$ setara dengan 60,40-61,48\% kebutuhan akan protein untuk beberapa kelompok umur. Dengan demikian sumbae basah berpotensi sebagai penurun berat badan pada obesitas.
\end{abstract}

Kata kunci: susu kecambah kedelai basah, protein, obesitas.

\section{Pendahuluan}

Angka kejadian obesitas makin meningkat dari tahun ke tahun. Pada tahun
2013, prevalensi obesitas perempuan dewasa (>18 tahun) 32,9\%, naik 18,1\% dari tahun $2007(13,9 \%)$ dan $17,5 \%$ dari 
tahun 2010 (15,5\%) (Riskesdas, 2013). Kondisi demikian terjadi seiring dengan meningkatnya kesejahteraan rakyat. Modernisasi juga membuat asupan kalori masyarakat menjadi tidak seimbang, karena didominasi karbohidrat. Obesitas dalam bentuk IMT $\geq 25 \mathrm{~kg} / \mathrm{m}^{2}$, merupakan faktor risiko penyakit degeneratif seperti diabetes melitus tipe 2, hipertensi, kardiovaskular, dan kanker (WHO, 2011; Lee et al., 2009). Gibney (2008) menambahkan bahwa $44 \%$ penyakit diabetes, $23 \%$ penyakit jantung, dan $41 \%$ penyakit kanker disebabkan obesitas. Menurut WHO (2011), satu diantara 10 orang dewasa mengalami obesitas. Di wilayah di Asia Tenggara, perempuan lebih banyak menderita obesitas dibanding pria, prevalensinya pada laki-laki $7,8 \%$, sedangkan pada perempuan $15,5 \%$ (Kemenkes RI, 2008). Joo (2011) menegaskan bahwa perkembangan obesitas dapat diupayakan dengan asupan gizi, khususnya dengan produk kaya protein tetapi rendah kalori.

Terkait dengan produk kaya protein, Winarsi dan Purwanto (2015) telah membuat susu kecambah kedelai dengan cara basah. Kelebihan susu kecambah kedelai adalah seluruh komponen penyusunnya telah terhidrolisis oleh enzim-enzim selama proses perkecambahan (Winarsi et al., 2010).
Menurut Aminah dan Hersoelistyorini (2012), kecambah kedelai dapat dibuat tepung dengan kadar protein tinggi dan memungkinkan dibuat produk susu kecambah dalam bentuk bubuk (kering). Produk kering memiliki keunggulan dibanding produk basah, seperti praktis penyediaannya, mudah handling, dan dapat dilakukan penyimpanan. Namun demikian, daya terima setiap individu terhadap produk pangan dalam bentuk kering ataupun basah sangat beragam.

Sebagian orang menyukai produk yang dibuat langsung dari bahan aslinya dengan pengolahan sederhana, tetapi tidak sedikit orang yang menyukai produk kering terkait kepraktisan dalam hal penyajian dan handling. Produk basah biasanya tampak fresh dan segar, demikian pula aroma aslinya juga masih terasa. Namun, bagi individu yang sering melakukan perjalanan jauh, biasanya memilih produk kering, karena dapat dibawa kemana-mana, ringan, praktis, dan awet. Demikian yang terjadi dengan produk minuman berbasis kecambah kedelai yang dikenal sebagai susu kecambah kedelai (Sumbae), dapat dibuat dengan cara basah dan juga cara kering (Winarsi dan Purwanto 2015; Winarsi et al., 2004).

Sumbae yang dibuat cara basah, tidak banyak melalui proses pengolahan, 
karena dibuat dari kecambah kedelai langsung, dibersihkan, diblender, ditambah susu, dan pemanis secukupnya (Winarsi dan Purwanto 2015). Sebaliknya sumbae yang dibuat dengan cara kering, harus melewati tahapan pembuatan tepung lebih dahulu, kemudian ditambahkan pemanis dan sedikit garam. Kedua metode tersebut tentu saja akan berdampak pada kandungan gizi produk.

Salah satu komponen gizi yang rentan terhadap proses pengolahan adalah protein. Dalilah (2006) menyatakan bahwa kandungan protein sangat bergantung pada pengolahan, misalnya pemanasan, pendinginan, dan goyangan. Karena itu, penggunaan 2 metode dalam pembuatan sumbae ini kemungkinan akan berdampak pada kandungan protein dan gizi lainnya, demikian pula terhadap daya terimanya.

Permasalahannya, bagaimana sifat organoleptik dan kandungan protein produk sumbae yang dibuat dengan cara basah dan kering? Penelitian ini bertujuan untuk mengetahui sifat organoleptik dan kandungan protein susu kecambah kedelai yang dibuat dengan cara basah dan cara kering.

\section{Metode}

Dalam penelitian eksperimen ini dibuat 2 produk sumbae dengan metode basah menurut Winarsi dan Purwanto
(2015), dan sumbae dengan metode kering berdasar temuan Aminah dan Hersoelistyorini (2012). Kedua produk tersebut diuji organoleptic dan kadar proteinnya, sehingga diperoleh produk yang disukai dengan kandungan protein tinggi.

\section{Pembuatan sumbae cara basah}

Ditimbang $1 \mathrm{~kg}$ kecambah kedelai, dibersihkan dari kotoran dan coteledonnya, kemudian ditambahkan susu bubuk sebanyak $30 \mathrm{~g}$, sukrosa $125 \mathrm{~g}$, dan garam 7-8 g. Semua bahan tersebut ditambahkan air hingga $5.000 \mathrm{ml}$, diblender hingga halus, kemudian disaring. Tahap selanjutnya adalah dipanaskan sampai hampir mendidih, lalu didinginkan. Susu kecambah kedelai dengan metode ini disebut sumbae basah (Winarsi dan Purwanto 2015).

\section{Pembuatan sumbae cara kering}

Dalam pembuatan sumbae kering ini, diawali dengan pembuatan tepung kecambah kedelai. Kecambah kedelai yang telah dibersihkan, dicuci, ditiris, dikukus lebih dahulu 3-5 menit, kemudian ditebarkan ke dalam loyang secara tipis-tipis, dikeringkan menggunakan cabinet dryer suhu $55^{\circ} \mathrm{C}, 6$ jam, hingga kering. Kecambah kering lalu diblender dan di ayak 100 mesh. Formula sumbae cara kering dibuat berdasarkan rendemen tepung yang diperoleh dari 
sejumlah kecambah kedelai (basah), sehingga kandungan gizinya tidak berbeda jauh dari sumbae yang dibuat dengan cara basah.

Sumbae kering dibuat dengan mengacu pembuatan susu kedelai kaya isoflavon temuan Winarsi et al. (2004) dan diperkirakan dengan rendemen tepung kecambahnya. Komposisi sumbae kering seperti berikut tepung kecambah kedelai 430 g, sukrosa 270 g, susu 70 g, dan garam 20 g. Seluruh bahan dicampur hingga homogeny, kemudian dibagi masingmasing $25 \mathrm{~g}$. Penyajiannya setiap $25 \mathrm{~g}$ sumbae kering diseduh dengan air panas sebanyak $200 \mathrm{ml}$ air, sehingga siap dikonsumsi.

\section{Uji organoleptic}

Uji organoleptic sumbae basah dan kering dilakukan oleh 52 orang panelis (Moskowitz et al., 2012), yaitu mahasiswa dan ibu-ibu PKK Desa Purwosari dan Pamijen. Pengujian organoleptic sumbae meliputi warna, rasa, aroma, dan kekentalan, dengan metode scoring berskala 1-5; 1 sangat tidak suka, 2, tidak suka, 3, agak tidak suka, 4, suka, 5, sangat suka. Panelis juga diminta untuk mengemukakan tingkat kesukaan atau ketidaksukaan dengan skala hedonik.

Secara teknis, sampel disajikan secara acak dan dalam waktu bersamaan.
Penyajian sampel menggunakan kode yaitu angka 3 digit, misalnya 303 untuk sumbae kering, dan 106 untuk sumbae basah. Panelis diminta untuk menilai setiap sampel dengan cara memberikan contreng $(\sqrt{ })$ di kolom formulir yang tersedia. Setiap selesai melakukan penilaian satu sampel, panelis diminta menetralisir dengan cara minum air putih, dan berhenti sekitar 10 detik, kemudian melanjutkan ke sampel selanjutnya.

\section{Uji proksimat sumbae}

Uji proksimat sumbae meliputi kadar protein, lemak, abu, dan protein (Sudarmadji et al., 1997).

\section{Penentuan produk sumbae yang dipilih}

Untuk memilih produk sumbae yang disukai dan kaya protein dilakukan uji efektifitas menurut Degarmo et al. (1984), dengan terlebih dahulu ditentukan besaran bobot variable dengan urutan sbb: kadar protein, rasa, warna, kekentalan, warna, dan energi.

\section{Analisis statistik}

Data yang diperoleh dianalisis menggunakan uji t, bila terdapat perbedaan dilanjutkan dengan uji DMRT dengan error $5 \%$.

\section{Hasil dan Pembahasan}

a) Hasil uji organoleptic sumbae yang dibuat cara kering dan cara basah ditampilkan dalam Tabel 1 berikut. 
Tabel 1. Score organoleptic sumbae kering dan sumbae basah

\begin{tabular}{lccc}
\hline \multirow{2}{*}{ Atribut } & \multicolumn{3}{c}{ Score } \\
\cline { 2 - 4 } & $\mathbf{3 0 3}$ & $\mathbf{1 0 6}$ & $\boldsymbol{p}=$ \\
\hline Warna & $3.13 \pm 0.99 \mathrm{~b}$ & $4.07 \pm 0.85 \mathrm{a}$ & 0,00 \\
Rasa & $3.25 \pm 0.79 \mathrm{~b}$ & $4.35 \pm 0.64 \mathrm{a}$ & 0,00 \\
Aroma & $3.33 \pm 0.82 \mathrm{a}$ & $3,83 \pm 0.59 \mathrm{a}$ & 0,11 \\
Kekentalan & $3.65 \pm 0.88 \mathrm{~b}$ & $4.25 \pm 0.79 \mathrm{a}$ & 0,028 \\
\hline
\end{tabular}

$\mathrm{N}=52$; 303, sumbae yang dibuat dengan metode kering; 106, sumbae yang dibuat dengan metode basah. Angka yang diikuti huruf berbeda pada baris yang sama menunjukkan adanya beda nyata pada taraf $\alpha$ 0.05. Skor kesukaan: 1 sangat tidak suka, 2, tidak suka, 3, agak tidak suka, 4, suka, 5, sangat suka.

b) Rata-rata hasil uji proksimat sumbae

\section{Organoleptik Sumbae} kering dan sumbae basah dipaparkan

\section{a). Warna}

pada Tabel 2 berikut.

Tabel 2. Hasil uji proksimat sumbae kering dan sumbae basah

\begin{tabular}{lccc}
\hline \multicolumn{1}{c}{ Komponen } & $\mathbf{3 0 3}$ & $\mathbf{1 0 6}$ & $\boldsymbol{P}=$ \\
\hline Kadar air (\%) & 79,401 & 80,133 & $1,65 \mathrm{E}-06$ \\
\hline Kadar abu (\%) & 0,077 & 0,072 & 0,011447 \\
\hline Kadar Protein (\%) & 13,311 & 13,771 & $9,11 \mathrm{E}-07$ \\
\hline Kadar lemak (\%) & 0,822 & 0,942 & 0,000691 \\
\hline Kadar karbohidrat $(\%)$ & 7,211 & 5,082 & $4,97 \mathrm{E}-06$
\end{tabular}

$\mathrm{N}=3$; 303, sumbae yang dibuat dengan metode kering; 106, sumbae yang dibuat dengan metode basah. Angka yang diikuti huruf berbeda pada baris yang sama menunjukkan adanya beda nyata pada taraf $\alpha$ 0.05 .

Kesan pertama yang didapat dari suatu produk makanan dan minuman adalah warna. Winarno (1992) menyatakan bahwa penilaian mutu bahan makanan pada umumnya sangat bergantung pada beberapa faktor diantaranya warna, rasa, tekstur, dan nilai gizinya. Namun demikian, sebelum faktor-faktor tersebut dipertimbangkan secara visual, seringkali warna lebih menentukan daripada faktor lainnya.
Nilai organoleptic untuk warna sumbae basah sebesar 4.07£0.85 (antara suka dan sangat suka) lebih tinggi daripada sumbae kering. Warna sumbae basah berbeda nyata dengan sumbae kering $(P=0,00)$. Sumbae kering yang diseduh warnanya krem agak coklat karena pengolahannya melalui beberapa tahap pemanasan, sedangkan sumbae basah warnanya putih cerah. Umumnya, panelis 
lebih menyukai warna cerah pada produk minuman, dibandingkan warna krem.

\section{b). Rasa}

Rasa dipengaruhi oleh beberapa faktor antara lain kandungan senyawa kimia, konsentrasi, suhu, dan interaksi dengan komponen rasa lainnya (Winarno, 1997). Rasa merupakan campuran dari respons cicipan dan aroma. Rasa sumbae dihasilkan dari campuran kecambah kacang kedelai dan susu, serta gula yang ditambahkan kedalamnya. Berdasarkan nilai kesukaan panelis terhadap rasa sumbae basah sebesar 4,25 (antara suka dan sangat suka), secara nyata lebih disukai dibandingkan sumbae kering $(3,25)(P=0,00)$.

Sumbae kering dibuat melalui proses pengeringan, dengan tujuan untuk mengurangi kadar air bahan, sehingga terhindar dari kerusakan mikroorganisme. Menurut Aminah dan Hersoelistyorini (2012), perubahan kecambah basah menjadi tepung atau bubuk memerlukan penghilangan air melalui beberapa tahap. Tentu saja selama proses pengurangan air terjadi perubahan sifat, struktur kimia, dan penampakan susu. Produk susu pada umumnya memiliki sifat yang sensitif terutama terhadap perlakuan panas ataupun aktivitas bakteri. Susu yang melalui proses pengeringan, kandungan air didalamnya menguap, dan seringkali menimbulkan rasa asam pada saat susu menjadi bubuk atau dalam keadaan kering (Lailiyah, 2014). Hal ini yang mempengaruhi penilaian panelis, sehingga lebih memilih sumbae basah daripada sumbae kering.

\section{c). Aroma}

Aroma adalah bau yang ditimbulkan oleh rangsangan kimia yang tercium oleh saraf olfaktori yang berada dalam rongga hidung saat makanan masuk ke dalam mulut (Peckham, 1969). Hasil penilaian uji oeganoleptik terhadap aroma sumbae kering sebesar 3,53, sedangkan sumbae basah sebesar 3,83, tidak ada perbedaan diantara keduanya $(P=0,11)$.

Winarno (1997) menambahkan bahwa aroma yang diterima oleh hidung dan otak lebih banyak merupakan campuran 4 aroma utama seperti harum, asam, tengik, dan hangus. Aroma makanan/minuman banyak menentukan kelezatan/kesegaran bahan makanan tersebut. Rendahnya senyawa antigizi dalam kecambah kedelai menjadikan aroma sumbae disukai panelis. Sumbae basah dibuat dalam kondisi fresh; dalam produk ini aroma harum lebih terdeteksi dibandingkan dalam sumbae kering yang biasanya telah mengalami penyimpanan.

\section{c) Kekentalan}

Kekentalan sumbae kering berbeda dengan sumbae basah $(P=0,02)$. Sumbae basah lebih disukai dibanding sumbae 
kering, meskipun kekentalannya lebih rendah atau encer. Wea (2014) dan Nurjanati (2017) menyatakan bahwa susu kecambah kacang hijau ataupun kacang merah lebih disukai karena kekentalannya rendah. Rendahnya kekentalan juga didukung oleh lebih tingginya kadar air sumbae basah dibanding sumbae kering (Tabel 2). Pada kenyataannya kandungan karbohidrat sumbae basah lebih rendah dibanding sumbae kering. Hal itu yang mendukung produk sumbae basah lebih encer, dibandingkan sumbae kering. Terlebih lagi, banyak pendapat bahwa pada umumnya orang lebih menyukai produk minuman yang kekentalan tidak tinggi karena membuat lambung cepat kenyang.

\section{Kandungan gizi sumbae}

Kandungan gizi sumbae tercermin dari hasil uji proksimatnya (Tabel 2).

\section{a) Kadar air sumbae}

Kadar air suatu produk minuman mencerminkan bentuk, tingkat kesegaran, serta daya terima konsumen. Kandungan air sumbae basah secara signifikan lebih tinggi dibanding sumbae kering $(P=1,65 E$ 06). Sumbae basah tidak melewati proses pengeringan, sehingga air yang terkandung didalamnya masih relative tinggi. Namun demikian, dengan kandungan air 80,133\% menjadikan sumbae basah disukai panelis, karena kepekatannya dirasakan tepat.

\section{b) Kadar protein sumbae}

Kadar protein sumbae basah lebih tinggi dibandingkan sumbae kering $(p=9,11 E-07)$. Protein sumbae basah 3,5\% lebih tinggi daripada sumbae kering. Proses pengeringan menyebabkan beberapa asam amino terbawa dalam air yang menguap, sehingga menurunkan kadar protein sumbae kering. Melalui proses perkecambahan semua komponen penyusun kedelai terhidrolisis oleh enzimenzim aktif, sehingga menjadikan produk sumbae mudah dicerna.

\section{c) Kadar lemak sumbae}

Sumbae basah memiliki kadar lemak lebih tinggi dibanding sumbae kering $(P=0,00069)$. Kemungkinan kadar lemaknya yang tinggi menjadikan rasa sumbae basah lebih disukai, karena lemak dapat mendukung rasa gurih/lezatnya suatu produk, sehingga bersama-sama kandungan protein memunculkan rasa enak.

\section{d) Kadar abu sumbae}

Kadar abu sumbae basah lebih rendah dibandingkan sumbae kering $(P=0,011)$. Sumbae basah tidak mengalami proses pengeringan, karena itu ada kemungkinan sebagian mineral masih terikat dengan senyawa lain, sehingga kadar abunya rendah. Kadar abu sumbae kering lebih tinggi dibanding sumbae basah, artinya bahwa kandungan mineral 
sumbae kering lebih tinggi dibanding sumbae basah. Beberapa mineral penting seperti $\mathrm{P}, \mathrm{K}, \mathrm{Ca}, \mathrm{Mg}, \mathrm{Mn}, \mathrm{Fe}, \mathrm{Al}, \mathrm{Cu}, \mathrm{Zn}$, dan $\mathrm{Na}$ dilaporkan Batal et al. (2010) terdapat dalam kedelai. Dalam penelitian ini belum ditentukan besarnya kandungan mineral dalam produk, kemungkinan jenisnya sama dengan mineral kedelai, tetapi jumlahnya berbeda. Berdasar kandungan mineral tersebut, Winarsi (2010) menambahkan bahwa produk berbasis kedelai dapat memperbaiki mineral tulang. Selain tingginya kadar abu, sumbae kering lebih awet karena dapat disimpan, demikian pula daya gunanya.

\section{e) Kandungan karbohidrat sumbae}

Terdapat perbedaan yang siginifan dalam kandungan karbohidrat sumbae basah dan kering $(P=4,97 E-05)$. Sumbae basah karbohidratnya 5,082\% sedangkan sumbae kering sebesar 7,21\%. Lama pengeringan berhubungan dengan pengurangan kadar air, semakin lama waktu yang digunakan dalam proses pengeringan, maka sumbae semakin rendah kadar airnya, sebaliknya kadar komponen lainnya, makin meningkat, termasuk karbohidratnya. Hal ini yang mendukung tingginya kadar karbohidrat dalam sumbae kering.

\section{f) Energi sumbae}

Besarnya energi sumbae terpilih didasarkan pada kandungan karbohidrat (4 kal), protein (4 kal) dan lemak (9 kal). Dari Tabel 2, dapat dihitung besarnya energi sumbae basah adalah $=13,771(4 \mathrm{kkal})+$ $0,942(9 \mathrm{kkal})+5,082(4 \mathrm{kkal})=83,89$ kkal. Besarnya energi 83,89 kkal per 100 $\mathrm{ml}$ sumbae. Bila per servingnya sebesar $250 \mathrm{ml}$, maka besarnya energi $=2,5 \mathrm{x}$ $83,89 \mathrm{kkal}=209,725 \mathrm{kkal}$.

\section{Indeks Efektifitas}

Berdasarkan uji indeks efektifitas dengan bobot variable protein 1, rasa hedonik 0,$9 ;$ aroma hedonik 0,8 ; kekentalan hedonik 0,7; warna hedonik 0,6; dan energy 0,5 didapatkan hasil nilai indeks efektifitas tertinggi adalah sumbae basah

(Table

3).

Tabel 3. Perhitungan indeks efektivitas

\begin{tabular}{lrrrrrr}
\hline & BV & \multicolumn{1}{c}{ BN } & NE (303) & NH (303) & NE (106) & NH (106) \\
\hline Protein & 1 & 0,222222 & 0 & 0 & 1 & 0,222222 \\
\hline Rasa & 0,9 & 0,2 & 0 & 0 & 1 & 0,2 \\
\hline Aroma & 0,8 & 0,177778 & 0 & 0 & 1 & 0,177778 \\
\hline Kekentalan & 0,7 & 0,155556 & 0 & 0 & 1 & 0,155556 \\
\hline Warna & 0,6 & 0,133333 & 0 & 0 & 1 & 0,133333 \\
\hline Energi & 0,5 & 0,111111 & 0 & 0 & 1 & 0,111111 \\
\hline Total & 4,5 & & & 0 & & 1 \\
\hline
\end{tabular}


Keterangan:

BV: Bobot Variabel; BN: Bobot Normal; NE: Nilai Efektifitas; NH: Nilai Hasil

Perhitungan :

- Jumlah seluruh nilai bobot variabel (BV): $1+0,9+0,8+0,7+0,6+0,5)=4,5$.

- $\quad \mathrm{BN}=\mathrm{BV} / \mathrm{Jumlah}$ seluruh BV

- $\quad$ Nilai Efektifitas $(\mathrm{NE})=\frac{\text { Nilai rata }- \text { rat perlakuan }- \text { Nilai rata }- \text { rata terendah }}{\text { Nilai rata-rata tertinggi }- \text { Nilai rata-rata terendah }}$

- $\quad \mathrm{NH}=\mathrm{NE} \times \mathrm{BN}$

- Jumlahkan seluruh NH, dimana hasil yang terbesar adalah perlakuan terbaik/terpilih.

3. Sumbae basah untuk pemenuhan

\section{kebutuhan beberapa kelompok usia} menurut Permenkes (2013)

Berdasarkan Permenkes (2013)

dapat diperhitungkan prosentase pemenuhan sumbae basah untuk kebutuhan beberapa kelompok usia (Tabel 4).

Tabel 4. Prosentase pemenuhan sumbae basah terhadap kebutuhan beberapa kelompok usia

\begin{tabular}{|c|c|c|c|}
\hline Komponen gizi & $\begin{array}{c}\text { Kebutuhan per } \\
\text { Kelompok usia } \\
19-29 \text { th } \\
30-49 \text { th } \\
50-64 \text { th } \\
\end{array}$ & $\begin{array}{c}\text { Kandungan gizi per } \\
\text { Serving sumbae basah } \\
(250 \mathrm{ml})\end{array}$ & $\%$ pemenuhan \\
\hline Energi (kkal) & $\begin{array}{l}2250 \\
2150 \\
1900\end{array}$ & 209,725 & $\begin{array}{l}9,32 \\
9,75 \\
0,11\end{array}$ \\
\hline Protein (g) & $\begin{array}{l}56 \\
57 \\
57\end{array}$ & 34,4275 & $\begin{array}{l}61,48 \\
60,40 \\
60,40 \\
\end{array}$ \\
\hline Lemak (g) & $\begin{array}{l}75 \\
60 \\
53\end{array}$ & 2,355 & $\begin{array}{l}3,14 \\
3,93 \\
4,44\end{array}$ \\
\hline Karbohidrat (g) & $\begin{array}{l}309 \\
323 \\
285\end{array}$ & 12,705 & $\begin{array}{l}4,11 \\
3,93 \\
4,46\end{array}$ \\
\hline
\end{tabular}

Sumbae basah memiliki kalori rendah. Per serving $(250 \mathrm{ml})$ hanya menyediakan $\quad 0,11-9,75 \%$ kebutuhan energi harian. Kacang-kacangan merupakan sumber protein alternatif, harganya murah dan dan mudah didapat. Mikkelsen et al. (2000) dan Winarsi et al.
(2013) melaporkan bahwa protein memberikan efek thermogenic dan satiety lebih besar dibandingkan dengan karbohidrat. Demikian halnya dengan sumbae basah yang menyediakan 60,40$61,48 \%$ kebutuhan protein harian bagi beberapa kelompok umur ini tentunya 
dapat menekan nafsu makan. Produk ini cocok dikonsumsi penderita obesitas, karena proteinnya yang tinggi membuat rasa kenyang lebih lama, sementara karbohidratnya yang rendah, tidak akan menambah berat badan. Winarsi et al. (2016) menambahkan bahwa $250 \mathrm{ml}$ sumbae basah yang dikonsumsi selama 2 bulan berturut-turut dapat mengurangi tingkat stres oksidatif ibu menyusui.

\section{Kesimpulan}

Susu kecambah kedelai basah lebih disukai dibandingkan susu kecambah kedelai kering, tercermin dari nilai rasa, warna, kekentalan, dan aromanya yang lebih tinggi. Sumbae basah memiliki kandungan protein tinggi, lebih tinggi 3,5\% dibandingkan kadarnya dalam sumbae kering. Per sajian sumbae basah, berturut-turut menyediakan protein $61,48 \%, 60,40 \%$, dan $60,40 \%$ dari kebutuhan hariannya bagi individu berumur 19-29 tahun, 30-49 tahun, dan 5064 tahun. Kalorinya yang rendah $(209,725$ kkal) didukung protein tinggi menjadikan produk sumbae basah cocok sebagai minuman alternatif bagi penderita obesitas.

\section{Ucapan terimakasih}

Ucapan terimakasih disampaikan kepada Yayasan Institut Danone Indonesia yang telah memberikan dana penelitian dalam bentuk Award Research Grant.

\section{Daftar Pustaka}

Aminah S, Hersoelistyorini W. 2012. Karakteristik kimia tepung kecambah serealia dan kacangkacangan dengan variasi blanching. Seminar Hasil-Hasil Penelitian - LPPM Unimus 2012.

Batal AB, Dale NM, Saha UK. 2010. Mineral composition of corn and soybean meal. The Journal of Applied Poultry Research, 19(4): 361-364. https://doi.org/10.3382/japr.201000206.

Dalilah E. 2006. Evaluasi nilai gizi dan karakteristik protein daging sapi dan hasil olahannya. Skripsi. IPB. Bogor.

Degarmo EP, Sullivan WG, Canada JR. 1984. Engineering Economy Seventh Edition, Macmillan Pub. Co, New York.

Gibney MJ. Gizi kesehatan masyarakat. Jakarta: EGC; 2008.

Joo N-S, Park, J-W, Park K-H, Kim, C-W, Kim B-T. 2011. Application of Protein-Rich Oriental Diet in a Community-Based Obesity Control Program. Yonsei Med J. 52(2): 249-256. doi: $10.3349 / y m j .2011 .52 .2 .249$

Kementerian Kesehatan Republik Indonesia. Riset Kesehatan Dasar tahun 2007. Jakarta: Badan Penelitian dan Pengembangan Kesehatan, Kementerian Kesehatan; 2008.

Lailiyah N. 2014. Pengaruh jumlah maltodekstrin dan lama pengeringan terhadap sifat organoleptik yoghurt susu kedelai bubuk. ejournal boga, 3(1): 65-78.

Lee YS, So JBY, Yap MD. Confronting the obesity epidemic: call to arms. Annals Academy of Medicine. 2009; 38 (1): 1-2.

Mikkelsen PB, Toubro S, Astrup A. 2000. Effect of fat-reduced diets on 24-h energy expenditure: comparisons between animal protein, vegetable protein, and carbohydrate. Am J Clin Nutr. 72(5):1135-41.

Moskowitz HR, Beckeley JH, Resurreccion AVA. 2012. Sensory and consumer research in food product design and development. $2^{\text {nd }}$ edition. IFT Press. Wiley-Blackwell. A John Wiley \& Sons, Ltd., Publication.

Nurjanati M, Winarsi H, Dwiyanti H. 2017. Efek lama perkecambahan terhadap sifat sensori dan kadar protein terlarut susu kecambah kacang merah (sukarah) untuk remaja obesitas. Universitas Jenderal Soedirman. 
Peckham, GC, 1969, Foundation of food preparation, 2nd eds, The Mac Millan Co, Callier Mac Millan Ltd, London

Riset Kesehatan Dasar (Riskesdas). 2013. Badan Penelitian dan Pengembangan Kesehatan Kementerian RI tahun 2013. http://www.depkes.go.id/resources/downloa d/general/Hasil\%20Riskesdas\%20 2013.pdf. [4 April 2018]

Sudarmadji S, Haryono B, Suhardi. 1997. Analisa Bahan Makanan dan Pertanian. Liberty Yogyakarta. Yogyakarta.

Wea ASY, Widodo R, Pratomo YA. 2014. Evaluasi Kualitas Produk Susu Kecambah Kacang Hijau, Kajian Dari Umur Kecambah Dan Konsenterasi Na-CMC, Jurnal Teknik Industri Heuristic, 11 (1) : 1693-8232.

Winarno FG. 1992. Kimia Pangan dan Gizi. PT. Gramedia Pustaka Utama. Jakarta. $253 \mathrm{Hlm}$.

Winarno FG. 1997. Kimia Pangan dan Gizi. Jakarta. Gramedia Pustaka Utama.

Winarsi H. 2010. Protein Kedelai \& Kecambah Manfaatnya bagi Kesehatan. Kanisius. Jogyakarta.

Winarsi H. 2013. Susu kecambah kedelai menurunkan marker il-6 dan berat badan ibu menyusui. Prosiding Seminar Nasional Patpi. Jember, 26-29 Agustus 2013.
Winarsi H, Muchtadi D, Zakaria FR, Purwantara B. 2004. Respons hormonal- imunitas wanita premenopause yang diintervensi minuman fungsional berbasis susu skim yang disuplementasi dengan $100 \mathrm{mg}$ isoflavon kedelai dan 8 mg Zn-sulfat. Jur Teknol dan Industri Pangan 15(1): 28-34.

Winarsi H, Purwanto A. 2015. Produk minuman fungsional berbasis protein kecambah kedelai untuk memperbaiki profil lipid penderita diabetes mellitus tipe- 2 beresiko tinggi penyakit jantung koroner dan proses pembuatannya. Paten IDP000039175.

Winarsi H, Purwanto A, Dwiyanti H. 2010. Kandungan Protein dan Isoflavon pada Kedelai dan Kecambah Kedelai. Biota 15(2): 212-218.

Winarsi H, Sasongko ND, Purwanto A. 2016. Germinated-soy milk in supressing inflammation and oxidative stress in blood plasma and breast milk of lactating mothers. International Food Research Journal 23(2): 646-652.

World Health Organization (WHO). 2011. Overweight and obesity [fact sheet on internet]. Departement of Sustainable Development and Healthy Environments. 2011 [cited 2013 Jul 4]. Available from: www.who.int/medicare/factsheets/fs311/en/. 